\section{The British Psychological Society Book Award 1998}

The Scientific Affairs board is inviting nominations for the Society's annual $£ 500$ Book Award to be received by 6 November 1998. Books published after 1 January 1995 which make a significant contribution to the advancement of psychology may be nominated and the author, or at least one co-author, should be resident in the United Kingdom. Edited collections of papers are not eligible, nor are books published by the Society. Nominators may be individuals, authors, publishers or their agents. Nominations should include the title of the book, the names(s) of the author(s), the publisher and the date of publication, plus a short statement not more than one side of A4 explaining why the author(s) should receive the Book Award. Copies of at least two published reviews of the book must be included, and a supporting statement by up to three additional referees with expertise in that field plus a copy of the book. should also be submitted whenever possible. Nominations should be addressed to the Chair of the Board, c/o Miss Lisa Morrison, Administrator. The British Psychological Society. St Andrews House, 48 Princess Road East, Leicester LEl 7DR (Telephone: 0116252 9510, e-mail: lismor@bps. org.uk).

\section{New publications}

Seminars in Psychosexual Disorders is the latest edition to the College Seminar Series. The series editors are H. Freeman, I. Pullen, G. Stein and G. Wilkinson, and the book looks at problems relating to sexuality. The first half of the book discusses what may go wrong between couples and how to deal with it, while the second part of the book devotes itself to disorders of sexual direction, examining the background and management associated with deviant sexual behaviour, with homosexual expression and gender problems. In the final chapters therapists with particular expertise give account of their therapeutic methods. Copies are available for $£ 15$ from: Book Sales, The Royal College of Psychiatrists, 17 Belgrave Square, London SW1X 8PG (Telephone: 01712352351 x146).

Ethnicity: An Agenda for Mental Health edited by Dinesh Bhugra sets the scene for identifying and meeting the mental health needs of Black and minority ethnic groups. In addition to multidisciplinary working, the key emphasis is in involving commissioners and voluntary organisations in deciding how best to meet the needs of the communities. Due to be published in the Autumn by Gaskell/The Royal College of Psychiatrists, copies will be available from the College Books Sales office (details as above).

The 1998 edition of At a Glance Guide to Current Medical Standards of Fitness to Drive issued by the Drivers Medical Unit, DVLA. Swansea is now available. All sections have been updated and revised, and some of the criteria have been changed. The Medical Advisers at the Medical Unit may be contacted on 01792783686 for further information. The booklet may be obtained, by enclosing a 38p SAE, from the DVLA, Drivers Medical Unit, Longview Road, Swansea SA99 1TU.

It's Only Natural is a video and booklet for parents, carers and others involved in the lives of young people with learning disabilities. Cost: $£ 70$ per set. £30 for individual parents and carers. Copies may be obtained from Pavilion Publishing (Brighton) Ltd, FREEPOST (BR458), 8 St George's Place, Brighton, East Sussex BN1 4ZZ (Telephone: 01273 623222, Fax: 01273 625526).

The Bonnie Tapes are three new videos documenting conversations about one woman's struggle with schizophrenia as seen by her parents and by her sister. Mental Illness in the Family, Recovering from Mental Illness and My Sister is Mentally II are priced \$59.95 each for institutional purchasers and \$29.95 for family members who prepay by check, MC or VISA. A $20 \%$ discount is available on purchase of all three videos. Further information/orders: Mental Illness Education Project Videos, 22-D Hollywood Ave, Hohokus, NJ 07423, USA (Telephone: 001201652 1989, Fax: 001201652 1973).

The 23rd edition of the Disability Rights Handbook provides updates and advice on all changes to disability benefits and legislation. Priced at $£ 11$ ( $£ 7$ for people claiming benefit), copies are available from The Disability Alliance, Educational and Research Association. Universal House, 88-94 Wentworth Street, London El 7SA (Telephone: 0171247 8776, Fax: 0171247 8765). 